\title{
Residence Selection in Banyumas District by Using Analytical Hierarchy Process Case Study: North and South Purwokerto Area
}

\author{
Yustina Meisella Kristania ${ }^{1}$, Aprih widayanto ${ }^{2}$, Joko Dwi Mulyanto ${ }^{3}$, \\ Nuzul Imam Fadlilah ${ }^{4}$, Chandra Kesuma ${ }^{5}$, Saifudin ${ }^{6}$ \\ \{yustina.yms@nusamandiri.ac.id ${ }^{1}$, aprih.apz@ nusamandiri.ac.id ${ }^{2}$, joko.jdm@ nusamandiri.ac.id ${ }^{3}$ \} \\ STMIK Nusa Mandiri Jakarta, Jakarta Indonesia ${ }^{123}$, Universitas Bina Sarana informatika, Indonesia ${ }^{456}$
}

\begin{abstract}
The need for a house continues to increase. It can be seen from the calculation data of resettlement needs in Banyumas district in 2013 of 64,236 homes. This study aims to determine of residence choice along with the criteria of the highest priority, which focused on 6 criteria that are type, facility, location, environment, security, and price in order to support the regulation of spatial and territorial layout plan of Banyumas District by using Analytical Hierarchy Process with 6 residence samples: Griya Satria Bukit Permata, Griya Kedungrandu Regency, Green Kanaya, Grand Satria Wiradadi II, and Griya Karang Indah The result shows that the residence type criteria have the highest weight of (0.358), and the highest residence priority is Griya Satria Bukit Permata residence with the value of 0.416 .
\end{abstract}

Keywords: analytical hierarchy process, residence selection, criteria, alternative.

\section{Introduction}

The house is a basic necessity with its function as a residence. The need for a house continues to increase, it can be seen from the calculation data of residential needs of Banyumas district in 2013 for 64,236 houses [1]. The banking credit facility that allows us to have a home in a short time is one of the developing factors of residence business in Banyumas where it can be seen by the number of applications for building permits and residence development. In 2012 there were 20 developers who got the site plan validation with a total land area of $297,528 \mathrm{~m} 2$ [2].

The determination of residence options should be based on the rules and requirements of each potential customer. Based on the regulation of spatial and territorial layout plan of Banyumas District, it is expected that the selected residential layout can pay attention to several elements, namely the availability of green open space, healthy house, and limited impact of industrial waste [2].

There are several aspects that can be used in decreasing the level of residence needs, which are the need based on the house function [3] [4] [5], needs based on hierarchy [6] [7], home needs based on urban residence area planning instructions [8], and house selection in accordance with aspects of the physical environment [9][10].

Analytical Hierarchy Process method is a method that can be used for decision making with various problems. Generally it can be divided into three main phases which are

ICCSET 2018, October 25-26, Kudus, Indonesia

Copyright (C) 2018 EAI

DOI 10.4108/eai.24-10-2018.2280521 
hierarchical structure [11], priority analysis [12][13], and verification of consistency. It requires paired comparison measurements to obtain priority scales with the weights to each of the criteria and alternatives used which allows for inconsistencies [14]. Priority Scale is used based on primary data collection in the form of interviews and questionnaires to the respondents that are potential customers and residence developer marketing.

Hariyanto et al. [15] from the analysis resulted in the location of the development settlement area located in Sukomanunggal district, the second priority was located in Sambikerep district, and the third priority was located in Lakarsantri district with the Analytical Hierarchy Process (AHP) method.

The comparisons were made by the judgment of decision makers by assessing the importance level of an element over other elements. The scale of paired comparison assessment with the intensity of its importance consists of several levels [16] which are seen in table 1 below.

Table 1. Paired Comparison Rating Scale.

\begin{tabular}{|c|c|c|}
\hline Relative intensity & Definition & Infromation \\
\hline 1 & Of equal value & Two requirements are of equal value \\
\hline 3 & Slightly more value & $\begin{array}{l}\text { Experience slightly favours one requirement } \\
\text { over another }\end{array}$ \\
\hline 5 & Essential or strong value & $\begin{array}{l}\text { Experience strongly favours one requirement } \\
\text { over another }\end{array}$ \\
\hline 7 & Very strong value & $\begin{array}{l}\text { A requirement is strongly favoured and its } \\
\text { dominance is demonstrated in pratice }\end{array}$ \\
\hline 9 & Extreme value & $\begin{array}{l}\text { The evidence favouring one over another is } \\
\text { of the highest possible order of affirmation }\end{array}$ \\
\hline $2,4,6,8$ & $\begin{array}{l}\text { Intermediate } \\
\text { between two adjacent } \\
\text { judgments }\end{array}$ & When compromise is needed \\
\hline
\end{tabular}

The best choice determination is taken through the priority score with the highest percentage. This paired comparison can be obtained through measurement of the level of importance, interest, emotion, experiences, and facts of a person, as the basis of a relative strength reflection scale.

Therefore, this research will analyze house planning in Banyumas District to determine the residence priority choice location which focused on 6 criteria that are type, facility, location, environment, security, and price to support spatial and territorial layout plan in Banyumas District by using Analytical Hierarchy Process (AHP). The results of this system will also form a map showing the location of the residence. 


\section{Research Method}

AHP focuses on the hierarchical structure of the decision to describe the problem in every situation faced by the decision maker. It uses the uncertainty factor by finding the closest

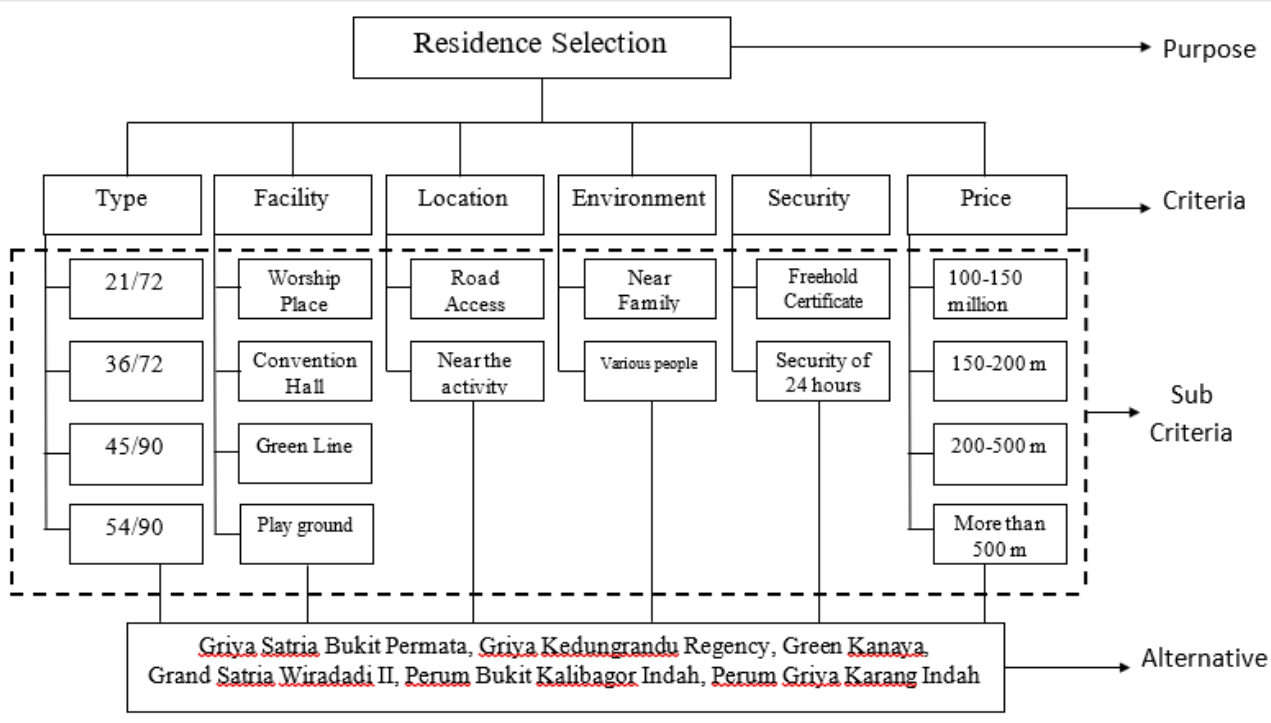

Fig. 1. Hierarchy Structure for Residence Selection.

Priority to the decision taken. In this study, there are four levels of hierarchy namely objectives, criteria, sub-criteria, and alternative solutions. A candidate that serves as an alternative was defined to choose residence to prospective customers.

\subsection{Calculating The Comparison Of Criteria}

The paired comparison is used to measure the criterion relationship with the initial goal of determining the alternative of residence selection. Giving weighting criteria based on the results of distributing questionnaires to communities in the area around North and South Purwokerto.

The validation value is calculated based on the number of respondents, rCount and rTable. Each respondent is given each of the 6 questions, which later answers from all respondents (15 respondents) will be calculated the level of correlation (rCount) of each question. Based on the number of respondents (15 respondents), the table obtained was 0,553 (significance level 0,05 ). The result of the validity of each question is $\mathrm{S} 1=0.553<0.856$, S2 $=0.553<0.973, \mathrm{~S} 3=0.553<0.775, \mathrm{~S} 4=0.553<0.963, \mathrm{~S} 5=0.553<0.928, \mathrm{~S} 6=0.553<$ 0.864 
Table 2. Matrix Of Paired Comparisons Of Each Criterion.

\begin{tabular}{lcccccc}
\hline Criteria & Type & Facility & Location & Environment & Security & Price \\
\hline Type & 1 & 7 & 5 & 3 & 3 & 2 \\
Facility & 0.143 & 1 & 1 & 0.333 & 1 & 0.143 \\
Location & 0 & 1 & 1 & 0.143 & 0.333 & 0.2 \\
Environment & 0.333 & 3 & 7 & 1 & 1 & 0.333 \\
Security & 0.333 & 1 & 3 & 1 & 1 & 0.333 \\
Price & 0.5 & 7 & 5 & 3 & 3 & 1 \\
Total & 2.509 & 20 & 22 & 8.476 & 9.333 & 4.009 \\
\hline
\end{tabular}

Based on table 2 above, the highest value is the total criteria value of the location with a value of 22. The criteria of the facility is the second highest total column value of 20 while the environment and price have the lowest total column value.

Table 3. Test Of Consistency Level To Criteria.

\begin{tabular}{lccc}
\hline Criteria & Priority & Eigen & Consistency \\
Type & 0.358 & 6.462 & Index \\
Facility & 0.056 & 6.257 & CI = (Eigen \\
Location & 0.046 & 6.201 & Max $-\mathrm{n}) /(\mathrm{n}-1)$ \\
Environment & 0.152 & 6.343 & Consistency \\
Security & 0.105 & 6.355 & Ratio \\
& & & CR $=$ CI / RI \\
Price & 0.284 & 6.534 & $=0.058$ \\
Total & & 38.151 & \\
Eigen Max & & 6.358 & \\
\hline
\end{tabular}

Based on table 3 above, it can be seen that the highest priority in determining the residence selection location is on the type criteria with the value of 0.358 and the lowest priority value on the location criterion of 0.046. The Consistency Index (CI) is 0.072, Random Index (RI) of 1.24 and the Consistency Ratio (CR) of 0.058 . Because the CR ratio rating is less than 0.1 , then this assesstment is acceptable.

\subsection{Determining The Alternative Priority Rating Of Each Paired Matrix}

After the priority value of each criterion was obtained, the priority of each residence as an alternative choice of prospective customers was calculated.

Table 4. Alternative Priority Values Of Type Criteria.

\begin{tabular}{|c|c|c|c|}
\hline Alternative & Priority & Eigen & \\
\hline Griya satria bukit permata & 0.447 & 0.152 & $\begin{array}{l}\text { Consistency Index } \\
\mathrm{CI}=(\text { Ejgen }\end{array}$ \\
\hline Griya kedungrandu & & & $\mathrm{CI}=\underset{(\mathrm{n}-1)}{(\text { Eigen Max }-\mathrm{n}) /}$ \\
\hline regency & 0.208 & $\begin{array}{l}0.149 \\
0.128\end{array}$ & $=-1.211$ \\
\hline Grand satria wiradadi ii & 0.150 & 0.180 & Consistency Ratio \\
\hline Griya karang indah & 0.047 & 0.150 & $\mathrm{CR}=\mathrm{CI} / \mathrm{RI}$ \\
\hline
\end{tabular}




$\begin{array}{ccc}\text { Total } & 0.769 & =-1.082 \\ \text { Eigen max } & 0.154 & \end{array}$

Based on table 4 above, it can be seen that the priority of each alternative to the highest type of criteria is the alternative of Grand Satria Bukit Permata Residence with the value of 0.447 and the lowest priority value in alternative of Griya Karang Indah Residence of 0.047 . The Consistency Index (CI) is -1.211 , the Random Index (RI) of 1.12, and the Ratio Consistency (CR) of -1.082 . Because the CR ratio rating is less than 0.1 , then this assessment is acceptable.

Table 5. Global Priorities And Rating Of Each Alternative

\begin{tabular}{lcc}
\hline \multicolumn{1}{c}{ Alternative } & Gloibal priority & Rating \\
\hline Griya satria bukit permata & 0.416 & I \\
Griya kedungrandu regency & 0.208 & II \\
Green kanaya & 0.193 & III \\
Grand satria wiradadi ii & 0.134 & IV \\
Griya karang indah & 0.048 & V \\
\hline
\end{tabular}

From the results of the alternative priority matrix in table 5, it can be explained that the alternative selection of residence areas in Banyumas district has the priority on the option of Griya Satria Bukit Permata Residence with a global priority value of 0.416 .

\section{Interface Design}

\subsection{Software Implementation}

The picure below shows the recommendation page used by the prospective consumer to give weight value for each criterion in the process of residence selection. Based on the literature study, the review that the author did has not been implemented into an application-based recommendation page that is used to give weight to each criterion in the process of determining the feasibility decision. 
Alternative Weight

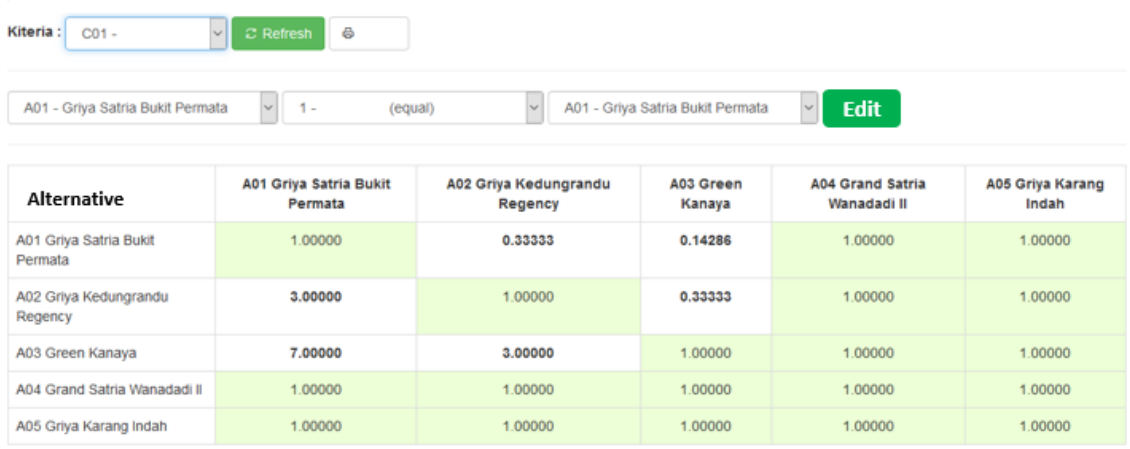

Process

Fig. 2. Weighting Recommendation Page.

\begin{tabular}{|c|c|c|c|c|c|c|}
\hline \multicolumn{7}{|c|}{ Alternative Calculations } \\
\hline Type & $\begin{array}{l}\text { A01 Griya Satria Bukit } \\
\text { Permata }\end{array}$ & $\begin{array}{l}\text { A02 Griya Kedungrandu } \\
\text { Regency }\end{array}$ & $\begin{array}{l}\text { A03 Green } \\
\text { Kanaya }\end{array}$ & $\begin{array}{l}\text { A04 Grand Satria } \\
\text { Wanadadi II }\end{array}$ & $\begin{array}{l}\text { A05 Griya Karang } \\
\text { Indah }\end{array}$ & $\begin{array}{l}\text { Priority } \\
\text { Vector }\end{array}$ \\
\hline $\begin{array}{l}\text { A01 - Griya Satria Bukit } \\
\text { Permata }\end{array}$ & 1.00000 & 3.00000 & 5.00000 & 1.00000 & 1.00000 & 0.33343 \\
\hline $\begin{array}{l}\text { A02 - Griya Kedungrandu } \\
\text { Regency }\end{array}$ & 0.33333 & 1.00000 & 1.00000 & 1.00000 & 1.00000 & 0.14966 \\
\hline A03 - Green Kanaya & 0.20000 & 1.00000 & 1.00000 & 1.00000 & 1.00000 & 0.14211 \\
\hline $\begin{array}{l}\text { A04 - Grand Satria } \\
\text { Wanadadi II }\end{array}$ & 1.00000 & 1.00000 & 1.00000 & 1.00000 & 1.00000 & 0.1874 \\
\hline A05 - Griya Karang Indah & 1.00000 & 1.00000 & 1.00000 & 1.00000 & 1.00000 & 0.1874 \\
\hline Total & 3.53333 & 7 & 9 & 5 & 5 & 1 \\
\hline \multicolumn{6}{|l|}{ Pricipal Eigen Value (Imax) } & 5.37873 \\
\hline \multicolumn{6}{|l|}{ Consistency Index (CI) } & 0.09468 \\
\hline \multicolumn{6}{|l|}{ Consistency Ratio (CR) } & 0.08454 \\
\hline
\end{tabular}

Fig. 3. Weighting Recommendation Page. 


\section{FINAL RESULT}

\begin{tabular}{|l|l|l|l|l|l|l|l|l|}
\hline \multicolumn{1}{|c|}{ Alternative } & C01 & C02 & C03 & C04 & C05 & C06 & Value & RANK \\
\hline Weight Eigen & 0.33574 & 0.14895 & 0.09998 & 0.11254 & 0.1514 & 0.1514 & \\
\hline A01 - Griya Satria Bukt Permata & 0.33343 & 0.11413 & 0.30633 & 0.2 & 0.2 & 0.2 & 0.24264 & 1 \\
\hline A03 - Green Kanaya & 0.14211 & 0.33996 & 0.25835 & 0.2 & 0.2 & 0.2 & 0.20725 & 2 \\
\hline A02 - Griya Kedungrandu Regency & 0.14966 & 0.17691 & 0.24392 & 0.2 & 0.2 & 0.2 & 0.18405 & 3 \\
\hline A05 - Griya Karang Indah & 0.1874 & 0.1845 & 0.09907 & 0.2 & 0.2 & 0.2 & 0.18337 & 4 \\
\hline A04 - Grand Satria Wanadadi II & 0.1874 & 0.1845 & 0.09233 & 0.2 & 0.2 & 0.2 & 0.1827 & 5 \\
\hline
\end{tabular}

Fig. 4. Weighting Recommendation Page.

\section{Conclusions}

Through the use of Analytical Hierarchy Process method, it is concluded that it can assist in developing hierarchy and defining alternatives to solve the existing problems. Through the weighting priority results, the residence type has the highest weight in the criteria of the prospective consumer determining the residence option with a value of (0.358).

The highest priority residence choice alternative with the first rank is in Griya Satria Bukit Permata Residence with the value of (0.416). This Decision Support System can also be used as a tool for prospective customers to determine residence selection by taking the final value of the highest-ranking residence.

\section{References}

[1] M. H. Suwargany, "PEMENUHAN PERUMAHAN UNTUK MASYARAKAT," pp. 174-182, 2017.

[2] B. On, "PENATAAN RUANG KABUPATEN BANYUMAS," 2013.

[3] eds C. M. John F C Turner \& Robert Fichter, “The John Turner Archive:," no. August, 1972.

[4] A. E. . Morris, History of Urban Form Before the Industrial Revolutions. London: Routledge, 2014.

[5] G. Meng, Gang \& Brent Hall, "Assessing housing quality in metropolitan Lima," J. Hous. Built Environ., vol. 21, no. 10.1007/s10901-006-9058-1, pp. 413-439, 2006.

[6] D. M. and K. Joomis, “人類需求 Maslow' s Hierarchy of Needs,” Eur. J. Soc. Sci., vol. 16, no. 13, p. 2001, 2007.

[7] B. T. Israel and D. Ph, "Using Design Psychology to Create Ideal Places," 2010.

[8] M. PU, "Pedoman teknis pembangunan gedung," vol. 2011, pp. 1-14, 2013.

[9] WHO Regional Office for Europe, "Sustainable development and health: Concepts , principles and framework for action for European cities and towns. European Sustainable Development and Health Series : Book 1.,” Heal. City Proj., p. 64, 1997.

[10] R. Barton, Hugh, Grant, Marcus, 1958- and Guise, Shaping neighbourhoods : a guide for health, sustainability and vitality. London: Spon, 2013.

[11] T. Millet, Ido \& Saaty, "On the relativity of relative measures - accommodating both rank preservation and rank reversals in the AHP," Eur. J. Oper. Res., vol. 121, no. 10.1016/S03772217(99)00040-5, pp. 205-212, 2000.

[12] R. W. Saaty, "The analytic hierarchy process-what it is and how it is used," Math. Model., vol. 9, no. 3-5, pp. 161-176, 1987. 
[13] D. Cheng, Eddie W.L. \& Li, Heng \& C.K. Ho, "Analytic hierarchy process (AHP): A defective tool when used improperly,” Meas. Bus. Excell., vol. 6, no. 10.1108/13683040210451697, pp. 33-37, 2002.

[14] T. L. Saaty, "Decision making with the analytic hierarchy process," Int. J. Serv. Sci., vol. 1, no. 1, p. 83, 2008.

[15] T. Hariyanto, C. B. Pribadi, and U. W. Deviantari, "Determination of Priority Location of Residential Area Development Using Analytical Hierarchy Process Method (Case Study: West Surabaya, East Java)," 7th Int. Annu. Eng. Semin., pp. 1-5, 2017.

[16] T. L. Saaty, "Fundamentals of Decision Making and Priority Theory with the Analytic Hierarchy Process,” Anal. Hierarchy Process Ser., vol. 6, 2000. 